\title{
Dairy tourism, a new facet of dairy entrepreneurship: Visitors' perception
}

\author{
Mahesh B Tengli, BS Meena, Pampi Paul and Santosh Onte
}

Received: 20 December 2018 / Accepted: 25 March 2019 / Published online: 22 June 2019

(C) Indian Dairy Association (India) 2019

\begin{abstract}
The republic of the India, have taken pledge of enhancing farmer's income, attracting and retaining youth in agriculture and other measures to bring paradigm shift in agriculture. Only 1.2 percent youths aspire to be farmers. Entrepreneurship opportunities in dairying beyond milk production and processing need to be thought of in order to enhance farmers' income and attract youth in dairy. In this context this study was conducted to identify scope for developing Dairy Tourism Model (DTM). The study was undertaken in the year 2016-2017, in the premises of milk parlour of ICAR-National Dairy Research Institute (NDRI), Karnal. The visitors of milk parlour were chosen as respondents. Data was collected from 100 visitors and the outcome of the study is concerned, dairy tourism is not a fully developed concept as other niche tourism, the prospective consumers were eager to realize this concept. The visitors' perceptions about dairy tourism were divergent and no consensus was arrived among them. This divergence is a gap that needs to be filled by means of an exploratory research in developing a dairy tourism model. One can anticipate that dairy tourism if realized can demand a share of value among other niche tourism.
\end{abstract}

Keywords: Dairy tourism, Inclination, Perception, Willingness to value

Mahesh B Tengli ( $₫)$, BS Meena

Division of Dairy Extension, ICAR-National Dairy Research Institute, Karnal, 132 001, Haryana, India

Email:mahidxndri16@gmail.com

Pampi Paul

Agricultural Extension, ICAR-RC-NEH, Umiam, India

Santosh Onte

Agronomy Section, ICAR-National Dairy Research Institute, Karnal, 132 001, Haryana, India
The republic of India, have taken pledge of enhancing farmer's income, attracting and retaining youth in agriculture, and other measures to bring paradigm shift in agriculture. Only 1.2 percent youths are aspire to be farmers (ASER, 2018). Seventy five percent of farmers want to quit farming (Lokniti Survey, 2014). Even, farmer's number dipped by 8.6 million (Census, 2011). On the other hand, there are listed reasons like dwindling land, climate change and less profit which are likely to lower the farmers' income. Economic condition is the driving factor for achieving any set of targets. Measures such as, improvement in productivity, increase resource use efficiency, intensive cropping, crop diversification, adapting non-farming occupation have been suggested by NITI aayog for enhancing farmers' income (NITI aayog, 2017). Dairying is another major game changing primary sector in the Indian economy. Making dairying more remunerative, attractive and diversified is a challenging job.

Farmers of Trans-Gangetic plains have been advised for replacing rice-wheat cropping system, as the boomerang effect of green revolution is being witnessed over a period of time. Farmers in general and dairy farmers in particular need to diversify by amalgamating with an economically viable, income \& employment generating activity. Cannarella's (2002) opined that farmer's income can be stabilized and cushioned from various risk factors by non- agricultural rural activity. Tew and Barbieri (2013) assert that farm diversification lead to increase in overall farm income. Diversification, according to Oredegbe and Fadeyibi (2009), is achieved by selecting and investing in assets in different sectors of the economy, which will assist in making up for losses in one sector with gains in another sector.

In the context of enhancing dairy farmers' income and making dairying attractive and remunerative, some of the questions can be put forth. What more can be done beyond dairy production and processing? What is that novel means of diversification of dairy farming? One such new dimension can be "Tourism". It has been already proven with many research studies on tourism potential of generating revenue and employment. Sarkar (2010) stated that Agri-tourism has the capacity for creating income opportunity for farmers and shows new path for rural development. Barbieri (2013) concludes his study by confirming that Agri-tourism produce environmental and socio-cultural 
benefits and it is successful in increasing farm profits, creating jobs and conserving the natural and cultural heritage. Welldesigned and well-managed tourism can make a significant contribution to the three dimensions of sustainable development (Economic, Social and Environmental), has close linkages to other sectors and can create decent jobs and generate trade opportunities (UNGA, 2015).

Based on the literature review and brainstorming we conceptualize dairy tourism as "the activity of providing, educational, recreational, exhibitory and enjoyment centering dairy animals, activities and products". This definition need to be more objective and researched. Thus the following characteristics of dairy tourism can be thought of; educating the visitors regarding dairy animals, their care and management, animal production, milk production and processing. Provide visitors an opportunity of training in dairying. Entertaining the visitor by allowing them to play with calf, milk the animal, animal grazing, animal riding, cart riding, animal circus etc., without harming the animals. Enjoy consuming dairy products, various sweets, drinks and other milk based food items. All the above characteristics it is perceived to be new niche tourism. With these all background literature and information the present survey research was conducted with the following objectives; to study the visitors' perception regarding dairy tourism, to study the visitors' inclination towards dairy tourism and to study the visitors' willingness to pay value to dairy tourism services.

The present study adopted exploratory and ex-post facto research design. Research was conducted in the year 2016-2017. The survey was conducted in the milk parlour of National Dairy Research
Institute (NDRI), Karnal, Haryana. Milk parlour is an outlet of different dairy products, produced in the institute, with beautiful recreation ambience. Total of 100 respondents (The customers of Milk Parlour) were selected using purposive sampling, the purpose was to select only those visitors who were willing to interact. A structured interview schedule which was pre tested and validated by experts was used to collect primary data. The collected data was analysed by using suitable statistical tools, and valuable inferences were drawn.

Visitors Socio-demographic profile, and travel behaviour pattern was studied using a schedule prepared Rajasenan, et al. (2012). From Table 1 it is clear that majority $(67.00 \%)$ of the respondents were belonging to middle age, 70.00 percent of respondents were male and rest were female. 56.00 percent of the respondents were graduates, with 56.00 percent of business men, 40.00 percent respondents were in the income range of Rs. 50,000 to Rs. 5, 00,000. Further 48.00 percent respondents' purpose of visiting tourist places was recreation and 41.00 percent of them want to visit eco-tourist place. The frequency of visit was concerned, 86.00 percent of them preferred to visit tourist places once in a year.

A teaser question was put to the respondents to study their awareness about "Dairy Tourism". From the figure 1, it is evident that 92.00 percent of respondents did not know about dairy tourism and they never heard about it but were willing to know about it. Only 8.00 percent of the respondents agreed to have some idea, but not able to comprehend exactly what is 'dairy tourism' all about. From this we can infer that the respondents were not aware of dairy tourism properly. This outcome may be due to

Table 1 Socio-demographic profile and travel behaviour pattern of respondents $(n=100)$

\begin{tabular}{lll}
\hline Parameters & Frequency & Percentage \\
\hline Age (35-49 years) & 67 & 67.00 \\
Gender Male & 70 & 70.00 \\
Female & 30 & 30.00 \\
Education: Graduates & 56 & 56.00 \\
Occupation: Business & 56 & 56.00 \\
Income : Rs. 50,000 /- to Rs. 5, 00,000/- & 40 & 40.00 \\
Purpose of visiting tourist places: Recreation & 48 & 48.00 \\
Preferred tourist destination: eco-tourist place & 41 & 41.00 \\
Frequency of visit : once in a year & 86 & 86.00 \\
\hline
\end{tabular}

Table 2 Distribution of respondents according to their perception regarding dairy tourism $(\mathrm{n}=100)$

\begin{tabular}{|c|c|c|c|}
\hline \multirow[t]{2}{*}{ What might be "Dairy Tourism" according to you? } & \multicolumn{3}{|c|}{ Response $(\%)$} \\
\hline & Agree & Neutral & Disagree \\
\hline An educational visit to dairy farm & 24.00 & 53.00 & 23.00 \\
\hline A visit to a rural dairy farm & 48.00 & 38.00 & 14.00 \\
\hline Eating dairy products from a dairy store & 4.00 & 38.00 & 58.00 \\
\hline It means eco-tourism & 14.00 & 34.00 & 52.00 \\
\hline A picnic spot to enjoy with dairy animals & 65.00 & 27.00 & 8.00 \\
\hline
\end{tabular}


Fig. 1 Distribution of respondents Do youknow what "Dairy Tourism" is? according to their awareness about dairy tourism $(\mathrm{n}=100)$

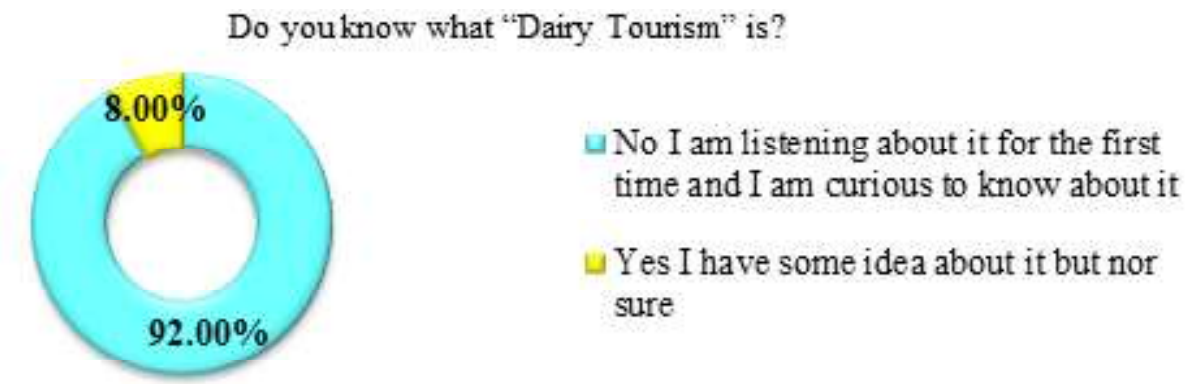

\section{Would you wish to visit a place where you can play with animals, feed them, care them and also have food items derived from them like milk products?}

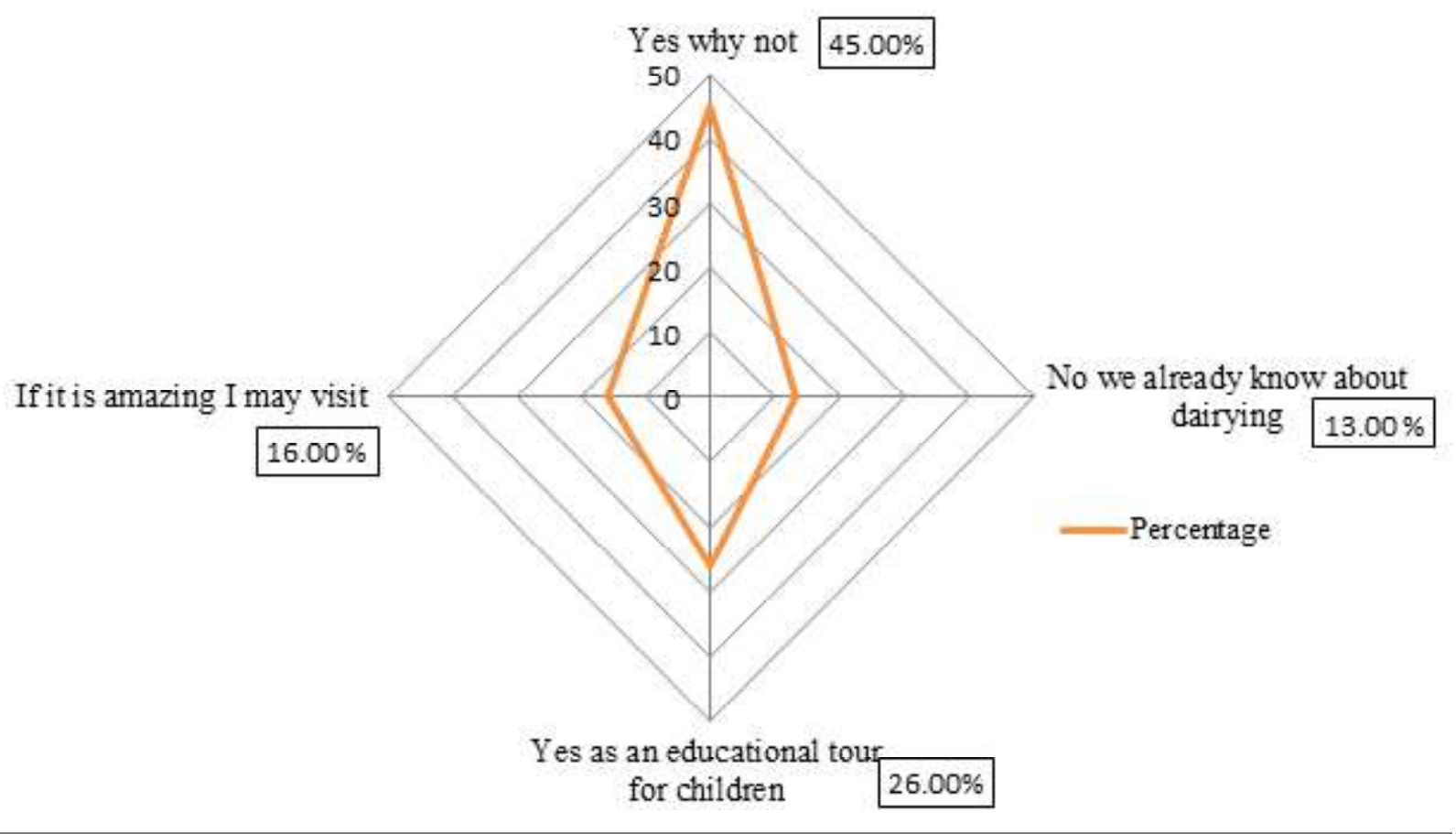

Fig. 2 Distribution of respondents according to their inclination towards dairy tourism $(\mathrm{n}=100)$

Table 3 Distribution of respondents according to their willingness to pay value to dairy tourism services ( $\mathrm{n}=100$ )

\begin{tabular}{|c|c|c|c|}
\hline \multirow[t]{2}{*}{ Willingness to pay value to dairy tourism services } & \multicolumn{3}{|c|}{ Response $(\%)$} \\
\hline & Agree & Neutral & Disagree \\
\hline $\begin{array}{l}\text { Dairy products have value but there is no need to pay for } \\
\text { farmers services }\end{array}$ & 0.00 & 12.00 & 88.00 \\
\hline Nothing is free of cost everything needs to be valued & 81.00 & 0.00 & 19.00 \\
\hline One need to pay and use the goods and services of farmers & 100.00 & 0.00 & 0.00 \\
\hline $\begin{array}{l}\text { Spending on family recreation such as in dairy tourism is not a } \\
\text { waste of money }\end{array}$ & 87.00 & 8.00 & 5.00 \\
\hline
\end{tabular}

their lack of exposure, lack of knowledge and as dairy tourism is not a fully developed concept in India. Thus we can conclude that 'Dairy tourism' needs to be studied.
Visitors were asked a question with the purpose of knowing what they perceived about dairy tourism. It is clear from the Table 2 that 24.00 percent of the respondents perceive that dairy tourism as an educational trip, 52.00 percent of them were unable to 
perceive dairy tourism as an educational trip. Further 48.00 percent of the respondents perceived dairy tourism means a visit to a rural dairy farm and 38.00 percent of them were neutral. Whereas 58.00 percent of the respondents perceived that dairy tourism is not about eating dairy products from a dairy store and 38.00 percent of them were unable to perceive anything.

52.00 percent of them also disagree with the statement that dairy tourism means "eco-tourism". Further 65.00 percent of respondents were in agreement to the statement stating dairy tourism as "a picnic spot to enjoy with dairy animals". From above findings one can infer that dairy tourism cannot only be about an educational trip, it is more than that. Whereas majority of the respondents were neutral about it, it can be attributed to the fact that they were not aware or perhaps the concept might have not existed in the locality of the respondent. Majority respondents were urban dwellers hence they might have perceived it to be a rural activity like rural tourism. As few respondents disagree that dairy tourism is a visit to rural dairy farm they might be trying to differentiate dairy tourism from rural tourism.

Respondents also disagree that dairy tourism is all about eating dairy products from a dairy store as they were already visiting a dairy milk parlor and they might have perceived what they were doing is not a dairy tourism activity. Further, the respondents did not perceive dairy tourism as eco-tourism; this outcome might be due to the awareness of the respondents about eco-tourism as 41.00 percent of them were willing to visit eco-tourism places. To sum up above observations we can articulate that the respondents were not clear about the concept of dairy tourism. The respondents also perceived dairy tourism beyond the existing tourism activities. This means there is a need and scope for developing a model dairy tourism for its socio-commercial utilization.

In order to study the inclination of the respondents towards dairy tourism, a question (fig.2) was asked by briefing what would dairy tourism be all about. The respondents replied with their agreement with one of the given four statements.

From the figure 2, it can be observed that 45.00 percent of respondents were willing to visit the proposed dairy tourism destination. Another 26.00 percent of the respondents were willing to visit it if it was educational dairy farm; it was observed that this response was agreed by most of the women respondents as they wanted their children to learn about how the milk is produced. Further 16.00 percent of respondents were willing to visit if the destination is amazing. And 13.00 percent of them have denied visiting as they were dairy farmers and from rural locality hence they showed no interest. From this we can roundup that respondents have affinity towards dairy tourism as it is new to them they wish to visit if realised. Everything has its value and without value nothing is worth. Similarly, what is the use of a business product which has no social and economic value? In order to assess whether the prospective consumers are willing to accord value to dairy tourism visitors' willingness to pay was studied.

From the table 3 , it is clear that 100.00 percent of the respondents were in agreement that one need to pay and use the goods and services, whereas 88 percent of them disagree with the idea of not paying for farmers' services. Around 87.00 percent of respondents agreed to spend on family recreation. Further, 81.00 percent of them believe that nothing is free of cost everything needs to be valued. From above outcomes it can be concluded that more than two third of respondents were willing to pay both social and economic value for dairy tourism. This outcome perhaps attributed to the observation that majority of the respondents were financially sound and educated which might have made them learn to value things. From this we can assume that if dairy tourism is realize it may receive some social and economic value which is of utmost important to farmers taking up dairy tourism.

\section{Conclusions}

From the above findings it can be concluded that dairy tourism is not a fully developed concept. This study identified a research gap as the respondents' perceptions about dairy tourism were diverse and no consensus was arrived on the concept of dairy tourism. This study paved a way for conceptualizing dairy tourism model which could be new venture for dairy farmers and other private investors to generate additional income and employment. Under the light of above findings a doctoral research is being undertaken to develop a "Dairy Tourism Model" by the first author.

\section{Acknowledgements}

We pay our gratitude to the manager NDRI milk parlour and all the respondents participated in the above study for their time and kind response.

\section{References}

ASER (2018) Annual Status of Education Report 2017 'Beyond Basics' (Rural). ASER Centre. New Delhi.

Barbieri C (2013) Assessing the Sustainability of Agri-tourism in the US: a comparison between agri-tourism and other farm entrepreneurial ventures. J Sust Tourism 21: 252-270

Cannarella (2002) Processes of marginalization of agriculture: the role of non-agricultural sectors to support economic and social growth in rural areas. J Central European Agric 3:205-216

Census (2011) Primary Census Abstracts, Registrar General of India, Ministry of Home Affairs, Government of India, and Available at: http://www.censusindia.gov. 
Economic Survey (2018) Economic Survey 2017-18. New Delhi, Ministry of Finance, Government of India.

Lokniti survey (2014) www.lokniti.org/pdf/Farmers_Report_Final.pdf.

NITI (2017) A policy paper on "Doubling farmer's income, rationale, strategy, prospects and action plan". National Institution for Transforming India. Pp-8.

Oredegbe A, Fadeyibi I (2009) Diversification into farm tourism. Paper presented at the International Conference on Regional and Urban Modeling. June, University of Ottawa, Ontario. http:// www.ecomod.net.
Rajasenan D, Varghese M, Bijith GA (2012) Tourist Profiles and Characteristics vis-à-vis Market Segmentation of Ecotourism Destinations in Kerala. J Econ Sust Dev 14:2222-2855

Sarkar S (2010) Agri-Tourism in India: A Way of Rural Development. Atna - J Tourism Stud 1: 52-59

Tew C and Barbieri C (2012) The perceived benefits of Agri-tourism: the provider's perspective. Tourism Management 33:215-224

UNGA (2015) Resolution 66/288, annex. A/C.2/70/L.5/Rev.1 